\title{
Factors associated with gender equality among church-going young men in Kinshasa, Democratic Republic of Congo: a cross-sectional study
}

Hendrew Lusey ${ }^{1,2,3^{*}}$, Miguel San Sebastian ${ }^{2}$, Monica Christianson ${ }^{3}$ and Kerstin E. Edin ${ }^{3}$

\begin{abstract}
Background: While women and girls are made vulnerable by inequitable and violent versions of masculinities, there is increasing evidence that gender equality will not be achieved without partnering with men. The aim of this study was to assess gender-equitable norms and their determinants among church-going young men in Kinshasa, the Democratic Republic of Congo.

Method: A cross-sectional study was carried out among 289 church-going young men, aged 18-24 years, residing in three disadvantaged communes of Kinshasa. Variables included sociodemographic characteristics, attitudes towards gender equality and responses to issues related to the Gender-Equitable Men (GEM) scale. Logistic regression was applied to identify the associations between sociodemographic characteristics, attitudes and the GEM scale.

Results: The findings provide evidence of attitudes and beliefs that act as barriers to gender equality. For instance, the majority of church-going young men (83.74\%) agreed that a man is the only decision maker in the home and about half (50.87\%) of the respondents supported the statement "There are times a woman deserves to be beaten". Similarly, around half of the participants agreed with the idea of men's uncontrollable sex drive (50.87\%) and men's toughness (50.17\%). Close to half of the participants (44.29\%) agreed that it is women's responsibility to prevent pregnancy. These attitudes co-existed with a few gender-equitable norms as $82.70 \%$ agreed on the importance of joint decisions concerning family planning. An association between education, certain places of residence, being single or separated, and supportive attitudes towards gender equality was found with higher scores for the GEM.

Conclusion: Our study findings indicate that a high proportion of church-going young men do not endorse genderequitable norms. Therefore, churches urgently need comprehensive gender equality and masculinity policies and programmes to influence young men's attitudes and behaviours. The promotion of gender equality in schools and the wider community also need to be encouraged.
\end{abstract}

Keywords: Gender equality, Gender-equitable men scale, Church-going young men, Masculinities, Cross-sectional study, DR Congo

\footnotetext{
*Correspondence: hendrewlusey@gmail.com

'World Council of Churches, Central Africa Regional Coordinator of the Ecumenical HIV and AIDS Initiative in Africa (EHAIA), C/o Salvation Army Headquarter, Avenue Colonel Ebeya no 23, B.P. 8636 Kinshasa Gombe, Democratic Republic of Congo

${ }^{2}$ Department of Public Health and Clinical Medicine, Epidemiology and

Global Health, Umeå University, Umeå, Sweden

Full list of author information is available at the end of the article
} 


\section{Background}

\section{Youth masculinities and health}

Policies and programmes that equate gender dimensions of health solely with the specific health needs of women have failed to address the evidence of gendered determinants that affect the health of both men and women [1]. Gender equality work - concerning the equal rights, responsibilities and opportunities of women, men, girls and boys - has tended to focus on the needs of women and girls. However, there is increasing recognition that gender equality will not be achieved without engaging men and boys as partners in the process [2]. Over the last decades, numerous programmes have sought to work with men and boys to challenge harmful norms of masculinities - what it means to be men [3] - with the purpose of improving the health of women, children and men. Some men and boys have significantly contributed to promoting gender-equitable attitudes and behaviours after programmatic interventions on masculinities [4]. For instance, after the implementation of some of such interventions in Brazil, India and Ethiopia, young men successfully changed their attitudes related to dominant versions of masculinities, particularly with regard to the negative consequences of actions that had made them and their partners vulnerable to HIV [5-7].

Nevertheless, inequitable norms of masculinity - those beliefs and expectations regarding positions and behaviours deemed appropriate for men and boys in a given society - may still put their health and that of their partners in jeopardy [8]. For instance, young men who internalise norms that emphasise sexual prowess and conquest as crucial in being a man [9] may have sex with multiple partners where protection is not an issue of concern [10]. They may also think that making a woman pregnant validates what it means to be a man [11] and may otherwise consider pregnancy prevention as the woman's responsibility [12]. Research suggests that young men may learn to view women as sexual objects and may use coercion to engage in sexual activities [13]. These beliefs and inequitable attitudes may begin in adolescence and may continue into adulthood in the absence of adequate spaces for reflection [14]. Therefore, engaging young men effectively in thinking critically about inequitable norms and taking concrete actions to promote gender equality can lead to better, longer, healthier lives and more fulfilling relationships for the young men themselves, as well as young women and children [15].

\section{Masculinities in sub-Saharan Africa and the positions of churches}

In sub-Saharan Africa (SSA), HIV is still a very serious public health problem as two thirds of people living with HIV reside in the region and some men are portrayed as key drivers [16]. The HIV epidemic and its implications for the population's health have motivated churches to address, among other approaches, issues of masculinities [17]. Traditionally, many African churches have been instrumental in addressing HIV prevention in accordance with the strategic priorities of the World Health Organization (WHO) and primary health care principles [18]. Churches have also learnt many lessons from HIV and AIDS responses that have been applied in the field of masculinities. For instance, a study has indicated that certain African churches could be contributing progressively to the transformation of harmful norms of masculinities [19]. Therefore, given the population coverage, churches in Africa may provide a compelling setting and a powerful socialisation platform for engaging large numbers of youth with positive attitudes and behaviours towards gender equality and with discourses such as those supporting positive forms of masculinities [20].

However, some church leaders' traditional views regarding what it means to be a man may reinforce harmful norms of masculinities that are prevalent in Africa [21]. Dominant versions of masculinities may partly be the result of selective reading and interpretation of the scriptures [22], lack of church leaders' commitment to promoting gender equality [23], and their real and/or perceived complacency in condoning harmful beliefs and practices about what it means to be a man [24]. For instance, a study found significant gender differences in many Mozambican churches, in which condom use was more likely to be discussed in men's rather than at women's meetings [25]. In spite of this, some church youth report that churches are very important to them and they still believe in the church message regarding masculinity issues [26]. Therefore, churches have an opportunity to explore and identify harmful beliefs, attitudes and practices regarding youth masculinities and work to overcome them [27].

\section{Masculinity studies in the Democratic Republic of Congo (DRC)}

The majority of Congolese consider themselves as believers, which include Catholic (31\%), Protestant (30\%), other Christian churches (34\%), indigenous religions (3\%) and Muslims (2\%). The church seems to play an important role in Congolese life and understanding how the church impacts on masculinity is necessary for designing an effective promotion of gender equality. The Ecumenical HIV and AIDS Initiative in Africa (EHAIA) has been strengthening the capacity of local church leaders by providing them with training and support to work with men and boys as part of the solution in transforming negative norms of masculinities and responding to HIV. A qualitative interview study conducted in the DRC indicated that the EHAIA's focus on masculinities resulted in some church youth embracing gender equality values (care, responsibility and nonviolence) as alternative ways of being a man [26]. 
With a focus on understanding men's practices and attitudes related to gender equality, the International Men and Gender Equality Survey (IMAGES) explored attitudes concerning gender relations, gender-based violence and the effects of conflict on women and men in Eastern DRC [28]. The IMAGES data suggested that both Congolese men and women ascribe to unequal gender norms that allow men to be sceptical about gender equality, while women have internalised these gender norms, transforming them into oppressed citizens. The same study also suggested that inequitable gender attitudes significantly affect women's sexual relationships. For instance, $62 \%$ of women and $48 \%$ of men surveyed said that a man has the right to sex even if a woman refuses [28]. Despite the invaluable DRC-IMAGES, there is a lack of masculinity and gender equality-related studies in a church-based environment and specifically among church youth, both internationally and in the DRC. In an attempt to fill this knowledge gap, this study aimed to assess genderequitable norms and their determinants among churchgoing young men in Kinshasa, the capital city of the DRC.

\section{Methods}

\section{Study setting}

This study was conducted in Bumbu, Camp Luka and Masina, 3 disadvantaged peri-urban communes out of the 24 situated in Kinshasa. The city has a population of nearly 12 million of a total population of 77 million in the DRC [29]. A convenient sample of three communes was selected because of the work that the Salvation Army and Eglise du Christ au Congo have developed with youth in the study settings and the collaboration between the first author and the leaderships of these churches. In this regard, the first author has been building the capacity of church leaders and church youth through masculinity workshops to equip them with the knowledge and skills to identify and fill gaps in male engagement programming related to HIV prevention, care, treatment and support. This has enabled the development of relevant and effective programmes and policies that have engaged men and young men in the responses of the church to HIV.

\section{Variables}

The overall questionnaire included 50 structured questions that were organised in three groups: sociodemographic characteristics, attitudes towards gender equality and the gender-Equitable Men (GEM) scale [30]. Certain items related to gender equality were used from the IMAGES project [30], one of most the comprehensive studies carried out in more than 20 countries (including the DRC) regarding men's practices and attitudes to gender norms, attitudes to gender equality policies, household chores, intimate partner violence, health and economic stress. Given the focus of our study on gender equality, health and economic stress were deliberately omitted. In our study, a few items regarding certain church aspects, such as church belonging, church attendance and attendance frequency were added to the sociodemographic characteristics.

\section{Sociodemographic characteristics}

Age was categorised in three groups (18-19, 20-21 and 22-24 years) and civil status included single, married/cohabiting and separated. Education comprised three levels: primary, secondary and university. Information on place of residence and church affiliation was also collected. Church attendance frequency had three categories: always, often and seldom. The main source of income included heads of households and young men's income. Labour status was dichotomised into employed and unemployed/students.

\section{Attitudes towards gender equality}

With regard to young men's perspectives on gender equality, six questions based on the IMAGES questionnaire were posed [31]. Responses to these questions fell into four categories, as participants were asked to ascertain whether they completely (1) or partly agreed (2) or they partly (3) or completely disagreed (4) with the statements. An index created by the sum of all the items was developed and divided in tertiles, representing low, medium and high levels of attitudes toward gender equality. The responses of church-going young men to the attitudes stated in the questionnaire are reported in Appendix.

\section{The gender-equitable men (GEM) scale}

Originally, the GEM scale was developed in response to the relative lack of tools required to measure quantitatively changes resulting from gender-related interventions [32]. The GEM scale resulted from qualitative research on gender norms with young men in low-income settings in Brazil, but has been validated in several contexts, including India, Kenya, Uganda and Nicaragua, as well as being adapted for the Ethiopian context [14]. The GEM scale has 24 items related to gender and domestic life, violence against women, sexual relationships, masculinities and sexual and reproductive health. In our study, the GEM questionnaire included a list of 16 statements only and we did not select the 8 remaining that we considered as irrelevant for young people. The participants were requested to indicate their extent of agreement (total agreement, partial agreement or disagreement) with a list of statements. The items were summed up and first grouped in tertiles for descriptive purposes and later dichotomised using the mean as the cut-off point for low and high GEM for the regression analysis.

\section{Recruitment and data collection}

This cross-sectional survey was conducted from March to April 2016. The first author received the French translated 
questionnaire from Promundo, which is a nongovernmental organisation founded in Brazil aimed at promoting caring, non-violent and equitable masculinities and gender relations [28]. The questionnaire was pre-tested among 10 young men from a church in a different but similarly disadvantaged commune of Kinshasa to the study participants. The pre-test sought to determine whether or not these items were clear, understandable and culturally relevant to the Congolese church youth context. In general, the participants considered the questionnaire appropriate, except for a few items that were re-worded by the study team. We reworded these items because we perceived them as inappropriate for the Congolese church youth context. For instance, one item was originally labelled as follows: "I would be outraged if my wife asked me to use a condom". Since most of the participants were single, we replaced the word "wife" by "partner."

To be included in this study, the participants had to be young men, aged 18-24 years, belonging to the Salvation Army or the Eglise du Christ au Congo, living in the above three communes and volunteering to participate. The Revival Churches of Congo were also contacted to participate but the leadership delayed its response and they were not included in the study. Once the study authorisation had been granted by the leadership of both churches involved, the first author contacted the respective pastors at the parish levels, who identified and recruited young men from local parishes, particularly on Sundays. When these pastors gathered the young men, the first author joined in to provide the self-administered questionnaire to the participants. These participants answered the questionnaire in church premises where the risk of disturbance was relatively low and they took approximately $1 \mathrm{~h}$ to complete the questionnaire.

In some cases, particularly for respondents who felt that certain statements were difficult for them to understand, the first author read each question to the respondent and then the respondent ticked the answers on the printed form of the questionnaire. The sample size calculation was based on the baseline prevalence of GEM of $50 \%$ as reported in other studies [6] and at the 5\% level with $80 \%$ power resulting in 370 individuals. In total, 400 young men were invited to participate, 50 were excluded for not meeting the inclusion criteria (including not being in the appropriate age range for the study, residing outside the study settings at the time at which data were collected, and belonging to a church other than the two selected), 50 did not show up and 11 declined the invitation for personal reasons. Finally 289 young men, who met the inclusion criteria, completed the questionnaire.

\section{Data analysis}

The survey responses were recorded on paper questionnaire forms, then entered into an Excel spreadsheet and later transferred into STATA 13.1 for statistical analysis. First, the percentages of responses related to the sociodemographic characteristics of the young men, attitudes towards gender equality and GEM were calculated. After that, logistic regression analysis was conducted to assess the relationships between the sociodemographic characteristics and the gender equality attitudes of the participants using the GEM scale. Crude and adjusted odds ratios and their 95\% confidence intervals were calculated. Significant variables in the crude model were included in the adjusted models.

\section{Ethical approval}

This study was approved by the institutional review board of the School of Public Health at the University of Kinshasa. Before doing the fieldwork, the first author requested written permission for the study from the Salvation Army and the Eglise du Christ au Congo leaderships. Also, the aim and purpose of the study were explained to the young men participating, who were ensured anonymity. Written informed consent was obtained from all the study participants.

\section{Results}

Table 1 presents the sociodemographic characteristics of the 289 young men (18-24 years old) of whom $55.36 \%$ were aged 18-19 years. The majority of the respondents (65.40\%) were single and had secondary school level education $(56.40 \%)$. The sample was equally distributed among the three communes. While most of these participants (91.70\%) were from the Salvation Army, only 8\% belonged to the Eglise du Christ au Congo. In the group of participants, $77.16 \%$ were church attendants and 40.83\% identified themselves as regular church attendants. When asked about their main reason to be in the church premises on the day of data collection, more than half (54.41\%) reported that they were attending the Sunday church services. While the main sources of income were from parents $73.70 \%$, almost one fourth (22.49\%) identified themselves as employed. Around one fifth (20.07\%) of church-going young men scored low in the gender attitude questions, with the majority (61.94\%) scoring moderate and another fifth (17.99\%) scoring high. Close to four out of ten $(38.75 \%)$ showed low support for inequitable gender norms, agreeing with statements of gender inequality, a third (30.10\%) had moderate scores for GEM (partly agree) and another third (31.14\%) had high scores (strongly agree).The majority of young men supported low and moderate gender equitable norms and only one third endorsed high GEM scores, meaning positive norms towards gender equity.

Table 2 shows the frequency of responses to the 15 questions included in the GEM scale. Overall, many participants (50-60\%) responded "totally agree" to all the 
Table 1 Sociodemographic characteristics, attitudes towards gender equality and GEM scores of church-going young men in Kinshasa

\begin{tabular}{ll}
\hline & $n(\%)$ \\
\hline Age group & \\
$18-20$ & $160(55.36)$ \\
$21-22$ & $67(23.18)$ \\
$23-24$ & $62(21.45)$ \\
Marital status &
\end{tabular}

$\begin{array}{ll}\text { Married/cohabiting } & 64(22.15) \\ \text { Single } & 189(65.40) \\ \text { Separated } & 36(12.46) \\ \text { Highest grade } & \\ \text { Primary school } & 27(9.34) \\ \text { Secondary school } & 163(56.40) \\ \text { University } & 99(34.26) \\ \text { Place of residence } & \\ \text { Bumbu } & 105(36.46) \\ \text { Masina } & 97(33.68) \\ \text { Camp Luka } & 86(29.86) \\ \text { Church affiliation } & \end{array}$

Salvation Army

Eglise du Christ au Congo

Church attendance

Yes

No

Attendance regularity

Always

Often

Seldom

Visit purposes

Sunday church service

Bible studies

Youth meetings

Main source of income

Young men themselves

Heads of households

Labour status

Unemployed/students

Employed

Attitudes to gender equality

Low

Medium

High

GEM

Low
265 (91.70)

24 (8.30)

$223(77.16)$

66 (22.84)

118 (40.83)

73 (25.26)

98 (33.91)

$158(54.41)$

58 (20.57)

$73(25.26)$

$72(24.91))$

$217(75.09$

$224(77.51)$

65 (22.49)

$58(20.07)$

179 (61.94)

$52(17.99)$

$112(38.75)$
Table 1 Sociodemographic characteristics, attitudes towards gender equality and GEM scores of church-going young men in Kinshasa (Continued)

\begin{tabular}{ll}
\hline & $n(\%)$ \\
\hline Medium & $87(30.10)$ \\
High & $9031.14)$ \\
\hline
\end{tabular}

items, highlighting that the study participants supported several inequitable gender norms. For instance, the majority (66.09\%) agreed that a woman's most important role is to care for her home and suggested changing diapers and feeding children were the mother's responsibility (64.05\%). Around half (50.87\%) of the young men agreed that men need more sex than women and (41.81\%) were of the opinion that men do not talk about sex, they just do it. The belief that men are always sexually ready, a sign of male virility, was also the subject of agreement for $45.33 \%$ of the respondents. More than half $(52.94 \%)$ of the participants concurred that men should be embarrassed if they unable to attain an erection. In addition, $44.29 \%$ of the young men were of the view that women were solely responsible for preventing pregnancy.

A significant proportion (47.40\%) of the young men indicated that they would be outraged if their partners asked them to use a condom. They also reported homophobic attitudes, with $57.44 \%$ declining a friendly relationship with a gay man. Half (50.17\%) of the young men agreed with the statement that men should be tough and most of them $(83.74 \%)$ also concurred that men have the final word concerning decisions in their homes. Nearly half $(47.40 \%)$ agreed that they would defend their reputation with force if they had to, for example if someone insulted them. In contrast, the same young men also tended to support certain equitable gender norms, with most $(82.70 \%)$ agreeing that a man and a woman should decide together if they want children. Similarly, nearly half $(41.52 \%)$ disagreed with the statement that women should tolerate violence to keep the family together.

Table 3 presents the logistic regression model for factors associated with high support (totally agree) on the GEM scale among young male churchgoers. In the crude analysis, several factors were significantly related to a higher GEM score. In the multivariate regression model, those who lived in the communes of Camp Luka and Masina also had higher odds on the GEM scale compared to those living in Bumbu and being single or separated was statistically significantly associated with high GEM values. A clear gradient in the association between attitudes to gender equality and the GEM scale was found, with those with more equal attitudes having higher odds on the GEM scale. Although education was not significant, higher GEM values were found among those with secondary education and above compared to 
Table 2 Church-going young men's scores on the GenderEquitable Men (GEM) scale

\begin{tabular}{|c|c|c|}
\hline Survey statements & Responses & $n(\%)$ \\
\hline \multirow{3}{*}{$\begin{array}{l}\text { A woman's most important } \\
\text { role is to take care of her } \\
\text { home and cook for her family }\end{array}$} & Totally agree & $191(66.09)$ \\
\hline & Partially agree & $49(16.96)$ \\
\hline & Disagree & $49(16.96)$ \\
\hline \multirow{3}{*}{$\begin{array}{l}\text { Men need more sex than } \\
\text { women }\end{array}$} & Totally agree & $147(50.87)$ \\
\hline & Partially agree & $93(32.18)$ \\
\hline & Disagree & $49(19.86)$ \\
\hline \multirow{3}{*}{$\begin{array}{l}\text { Men don't talk about sex; you } \\
\text { just do it }\end{array}$} & Totally agree & $119(41.18)$ \\
\hline & Partially agree & 87 (30.10) \\
\hline & Disagree & $83(28.72)$ \\
\hline \multirow{3}{*}{$\begin{array}{l}\text { There are times when a } \\
\text { woman deserves to be } \\
\text { beaten }\end{array}$} & Totally agree & $147(50.87)$ \\
\hline & Partially agree & $85(29.41)$ \\
\hline & Disagree & $57(19.72)$ \\
\hline \multirow{3}{*}{$\begin{array}{l}\text { Changing diapers, giving a } \\
\text { bath, and feeding kids is the } \\
\text { mother's responsibility }\end{array}$} & Totally agree & $185(64.05)$ \\
\hline & Partially agree & $53(18.34)$ \\
\hline & Disagree & $51(17.65)$ \\
\hline \multirow{3}{*}{$\begin{array}{l}\text { It is a woman's responsibility } \\
\text { to avoid getting pregnant }\end{array}$} & Totally agree & $128(44.29)$ \\
\hline & Partially agree & $99(34.26)$ \\
\hline & Disagree & $62(21.45)$ \\
\hline \multirow{3}{*}{$\begin{array}{l}\text { A man should have the final } \\
\text { word about decisions in his } \\
\text { home }\end{array}$} & Totally agree & $242(83.74)$ \\
\hline & Partially agree & $29(10.03)$ \\
\hline & Disagree & $18(6.23)$ \\
\hline \multirow{3}{*}{$\begin{array}{l}\text { Men are always ready to have } \\
\text { sex }\end{array}$} & Totally agree & $131(45.33)$ \\
\hline & Partially agree & 96 (33.22) \\
\hline & Disagree & $62(21.45)$ \\
\hline \multirow{3}{*}{$\begin{array}{l}\text { A woman should tolerate } \\
\text { violence to keep her family } \\
\text { together }\end{array}$} & Totally agree & $109(37.52)$ \\
\hline & Partially agree & $60(20.76)$ \\
\hline & Disagree & $120(41.52)$ \\
\hline \multirow{3}{*}{$\begin{array}{l}\text { I would be outraged if my } \\
\text { partner asked me to use a } \\
\text { condom }\end{array}$} & Totally agree & $137(47.40)$ \\
\hline & Partially disagree & $87(30.10)$ \\
\hline & Disagree & $65(22.49)$ \\
\hline \multirow{3}{*}{$\begin{array}{l}\text { A man and a woman should } \\
\text { decide together if they want } \\
\text { to have children }\end{array}$} & Totally agree & $239(82.70)$ \\
\hline & Partially agree & $28(9.69)$ \\
\hline & Disagree & $22(7.61)$ \\
\hline \multirow{3}{*}{$\begin{array}{l}\text { I would never have a gay } \\
\text { friend }\end{array}$} & Totally agree & $166(57.44)$ \\
\hline & Partially agree & $53(18.33)$ \\
\hline & Disagree & $70(24.22)$ \\
\hline \multirow{3}{*}{$\begin{array}{l}\text { If someone insults me, I will } \\
\text { defend my reputation, with } \\
\text { force if I have to }\end{array}$} & Totally agree & $116(40.28)$ \\
\hline & Partially agree & $91(31.60)$ \\
\hline & Disagree & $82(28.12)$ \\
\hline \multirow{4}{*}{$\begin{array}{l}\text { To be a man, you need to be } \\
\text { tough }\end{array}$} & Totally agree & $145(50.17)$ \\
\hline & Partially agree & $85(29.41)$ \\
\hline & Disagree & $59(20.42)$ \\
\hline & Totally agree & $153(52.94)$ \\
\hline
\end{tabular}

Table 2 Church-going young men's scores on the GenderEquitable Men (GEM) scale (Continued)

\begin{tabular}{lll}
\hline Survey statements & Responses & $n(\%)$ \\
\hline $\begin{array}{l}\text { Men should be embarrassed } \\
\text { if they are unable to get an } \\
\text { erection }\end{array}$ & Partially agree & $68(23.53)$ \\
\hline
\end{tabular}

those with primary education. Similarly, though the association was not significant, men who always attended church services had higher odds of high GEM scores compared to those who seldom attended the church.

\section{Discussion}

Our research findings show attitudes and beliefs that may act as potential barriers for gender equality among church-going young men. They scored highly on genderinequitable norms concerning statements regarding attitudes related to gender and domestic life, violence against women, what it means to be a man, sexuality and reproductive and sexual health. In spite of this, our study also offers some hope for change as participants also tended to support a few equitable gender norms. An association between education, certain places of residence, being single or separated, and supportive attitudes towards gender equality was found with higher scores on the GEM scale. In the following section, first we consider the GEM dimensions and then compare our findings to those of similar studies. Finally, we offer some reasons for the differences and discuss the results of the regression analysis.

\section{GEM domains}

\section{Gender and domestic life}

Research suggests that men may strongly adhere to unequal gender norms, holding women responsible for domestic duties and child care and viewing men as the final decision makers in the home $[26,28,32,33]$. Most $(74.5 \%)$ of the men in DRC-IMAGES [28] agreed that "a woman's most important role is to take care of her home and cook for her family", reflecting a similar proportion in a study in Rwanda (83.1\%) [33] and our own study (83.05\%) [31, 33]. Similarly, our findings show a higher reluctance among young men to participate in child care, with $83.05 \%$ agreeing that changing diapers, feeding and giving children a bath are a mother's responsibility, compared to $53.3 \%$ in DRC-IMAGES [28] and $61.2 \%$ in Rwanda [31, 33]. We found also a strong emphasis on the traditional positions of men as the head of the household. This was depicted in the belief that a man should have the final word about decisions in his home, $93.77 \%$ in our study compared to $75 \%$ in DRC-IMAGES [28], 65.9\% of men in Rwanda and 80\% in India [31,33].

\section{Violence against women}

Studies have shown that respondents who provide support for inequitable gender norms are also more likely to 
Table 3 Factors related to high GEM reported by church-going young men: logistic regression analysis with crude and adjusted odds ratios (OR) and their 95\% confidence intervals (Cl)

\begin{tabular}{|c|c|c|}
\hline Factors & Crude OR (95\% Cl) & Adjusted OR $(95 \% \mathrm{Cl})$ \\
\hline \multicolumn{3}{|l|}{ Age } \\
\hline $23-24$ & 1 & - \\
\hline $21-22$ & $0.56(0.28-1.12)$ & - \\
\hline $18-20$ & $1.02(0.57-1.84)$ & - \\
\hline \multicolumn{3}{|l|}{ Education } \\
\hline Primary school & 1 & 1 \\
\hline Secondary school & $3.04(1.22-7.58)$ & $2.65(0.99-7.11)$ \\
\hline University & $3.43(1.33-8.84)$ & $2.54(0.90-7.16)$ \\
\hline \multicolumn{3}{|l|}{ Place of residence } \\
\hline Bumbu & 1 & 1 \\
\hline Camp Luka & $2.53(1.41-4.56)$ & $2.27(1.18-4.38)$ \\
\hline Masina & $3.10(1.75-5.52)$ & $3.29(1.73-6.25)$ \\
\hline \multicolumn{3}{|l|}{ Civil status } \\
\hline Married/cohabiting & 1 & 1 \\
\hline Single & $2.75(1.51-5.02)$ & $3.20(1.64-6.25)$ \\
\hline Separated & $2.75(1.18-6.39)$ & $3.54(1.36-9.21)$ \\
\hline \multicolumn{3}{|l|}{ Job status } \\
\hline Employed & 1 & - \\
\hline Unemployed & $1.05(0.78-1.40)$ & - \\
\hline \multicolumn{3}{|l|}{ Church affiliation } \\
\hline Salvation Army & 1 & - \\
\hline Eglise du Christ au Congo & $0.69(0.30-1-60)$ & - \\
\hline \multicolumn{3}{|l|}{ Church attendance } \\
\hline No & 1 & - \\
\hline Yes & $1.07(0.61-1.85)$ & - \\
\hline \multicolumn{3}{|l|}{ Attendance frequency } \\
\hline Seldom & 1 & - \\
\hline Often & $1.02(0.55-1.88)$ & - \\
\hline Always & $1.49(0.87-2.56)$ & - \\
\hline \multicolumn{3}{|l|}{ Main sources of income } \\
\hline Young men & 1 & - \\
\hline Parents & $1.46(0.85-2.50)$ & - \\
\hline \multicolumn{3}{|l|}{ Attitudes to gender equality } \\
\hline Low equity & 1 & 1 \\
\hline Medium equity & $2.00(1.07-3.76)$ & $2.56(1.30-5.04)$ \\
\hline High equity & $9.33(3.84-22.63)$ & $7.09(2.81-17.89)$ \\
\hline
\end{tabular}

use physical and sexual violence against their partners [32]. While having similar prevalence with other studies $[28,31,33]$, with rates of $60-65 \%$ regarding the statement: "A woman should tolerate violence in order to keep her family together", $80.21 \%$ of our study participants strongly agreed that "there are times when a woman deserves to be beaten", compared to the DRC-
IMAGES (61.9\%) [28] and studies in India (64.4\%) [33] and South Sudan (63\%) [34]. These gender inequitable norms prevailing in the DRC may attest to the reasons why this country has the highest rates of intimate partner violence and sexual violence compared to other countries in which IMAGES projects have been conducted [28].

\section{Sexual relationships}

Gender norms that dictate what is appropriate or expected regarding sexual behaviours for men and women may encourage risk behaviours, particularly among young men [35]. An example of such gender norms is the view that men need more sex than women, a view endorsed by $67.83 \%$ of church-going young men, similar to DRCIMAGES (70.5\%) [28]. The belief that men are always ready to have sex was held by $78.55 \%$ of our study participants, $65 \%$ of men in DRC-IMAGES [28] and $46 \%$ in a study conducted in Ethiopia [7]. These findings, including ours, suggest that Congolese men strongly adhere to unequal gender norms and tend to be sceptical concerning gender equality as they think that they have a "right to have sex", particularly with their female partners, even if their partners refuse [28].

\section{Masculinities}

Research in African contexts has shown that masculinity ideals give centrality to toughness, strength and heterosexual performance [36]. In various studies, the majority of men $(79.58 \%$ in our study, $85.8 \%$ in a GEM study in India and $73 \%$ in Bosnia) concurred that to be a man you need to be tough [33]. This may suggest the pressure facing young men to exert power and authority over women and other men to gain praise and recognition for their masculinities [37]. In addition, a study in Uganda has documented stereotypes defending reputation and strength being equated with what it means to be a man for fear of social embarrassment [38]. In this regard, $71.88 \%$ of our study participants, compared to 55.3\% in DRC-IMAGES [28] and 91.7\% in India [31, 33], were of the view that if somebody insulted them, they would defend their reputation, with force if they have to. Research indicates that homophobia is perceived as an expression of masculinity [39]; indeed, $75.77 \%$ of our study participants and 65\% in DRC-IMAGES [28] would deny a friendship with a gay man. Our findings are consistent with research in India and Bosnia, reporting that men feel uncomfortable ( $92 \%$ and $56.8 \%$ respectively) when in contact with a gay man [40].

\section{Sexual and reproductive health}

Social norms and attitudes which put men in a position of sexual dominance may be related to unsafe sexual behaviours with potential negative consequences inhibiting women from controlling their own sexual and reproductive health [14]. These norms dictate that it is men's responsibility 
to acquire condoms as a woman carrying condoms may be viewed as "easy". Moreover, as many as $77.50 \%$ of the young men in our study, 66.4\% in DRC-IMAGES [28] and 52\% in a Tanzanian study [41] agreed that they would be outraged if their partner asked them to use a condom. In many settings, the prevailing norms indicate that sexual and reproductive health is perceived as "a female domain" and therefore it is a woman's responsibility to avoid getting pregnant [12, 42]. In our study $78.55 \%$ agreed with this statement versus $61 \%$ in DRC-IMAGES [28, 43]. Yet, gendered power dynamics may prevent certain women from negotiating condom use even when they wish to do so [33]. In spite of these persistent inequitable attitudes, our respondents emphasised the importance of mutual family planning. For instance, $92.39 \%$ of church-going young men agreed that a man and a woman should decide together if they want children.

Compared to DRC-IMAGES [28] and GEM findings from other studies carried out in Brazil, Chile, Croatia, India, Mexico and Rwanda [31, 33, 44], church-going young men in our study setting in DRC mainly scored inequitable statements, which could be due to several reasons. Research suggests that social expectations of what it means to be a man might remain reinforced at individual and community levels for young men who live in areas where they may have few opportunities to challenge their beliefs and attitudes with those modelling alternative masculinities [28]. Another study indicated that young men from disadvantaged areas and backgrounds face many challenges, including lower levels of health-promoting behaviours, poor health outcomes and lack of social support from parents and friends [45]. Therefore, church-going young men living in disadvantaged areas such as in our study may continue to be influenced by the same harmful norms of masculinity and socioeconomic health inequalities as the rest of society supporting inequitable norms [17].

In addition, research has highlighted that some Christian views and negative cultural aspects regarding patriarchy tend to reinforce each other in certain churches, which may provide considerable power to men and young men $[43,46]$. Some churches may even reinforce harmful norms of masculinity through skewed teachings and interpretations of the scriptures and these may be embraced by church-going young men [22]. In this regard, a masculinity-related study conducted in Zambia found church-going young men who referred to the Genesis creation story as evidence of male superiority [47]. This is an indication that scriptures may be used and abused by young men to engage in risky sexual behaviours and to display oppressive attitudes towards women and girls.

The Salvation Army is a progressive church in this regard since priesthood vocation is open and accessible to both women and men. However, we still agree that unequal gender relations and opinions might exist between priest women and men [21]. Moreover, the church efforts that have been undertaken so far by the Ecumenical HIV and AIDS Initiative in Africa in this study population to promote positive forms of masculinities and gender equality might have reached only a small proportion of church-going young men [26]. While some church hierarchies and policies might express progressive views on gender equality, members of some congregations might not endorse egalitarian attitudes and relations. Research shows that masculinity and gender equality issues might be fairly new subjects for some Congolese churches, which thus might not have effective policies and programmes addressing such issues [26].

\section{Determinants of gender-equitable norms by men}

Logistic regression models were used to identify associations between sociodemographic characteristics, attitudes to gender equality and the GEM scale. The regression analysis showed that being educated, living in Camp Luka and Masina, being single or separated, and having supportive attitudes towards gender equality were significantly associated with high support for GEM. Although education was not statistically significant in the adjusted model, probably due to the small sample size, the results seem to point to the importance of formal education. Research has shown that educated men exposed to broader ideas about gender may socialise with other people, expand their minds and question certain norms regarding what it means to be a man. In addition, they may have progressive views of gender equality and may be aware of its importance [40].

Another important set of findings in our study was that young men living in Camp Luka and Masina and those who were single or separated had high GEM scores. The association between living in Camp Luka and Masina and high support for GEM was unexpected as the areas selected for this study shared similar patterns in terms of sociodemographic characteristics and church affiliations. In contrast, the observed association between being separated and high support for GEM was found in DRC-IMAGES [28], in which unmarried and non-cohabiting men with children were more likely to report increased participation in child care [33]. This might be an indication that these men spend quality time with their children outside their mothers' homes and/or in the absence of their mothers [28]. Qualitative studies may be needed to gain a better understanding of such differences in both cases.

In our study, the strongest association was found between supportive attitudes towards gender equality and high scores for GEM (strongly agree). This was expected as research using the GEM scale has shown how working with men and boys to promote gender equality can contribute to achieving positive forms of masculinities [48]. These include less oppressive, non-violent, caring and equitable forms of masculinities progressively emerging in SSA and elsewhere [49]. The IMAGES projects carried out in Brazil, 
Chile, Croatia, India, Mexico and Rwanda have confirmed these findings [31]. Similarly, other study findings [31, 33], including ours, indicate that men with equitable attitudes are more likely to report an active participation in household duties, effective communication with their female partners and reduced use of violence.

Despite the lack of statistical association, probably due to the relative small sample size, young men who always attend church services had a better GEM score than those who rarely attended. Though more work needs to be done, this might imply that churches have the potential to support gender equitable norms among young men. This finding is consistent with that of a masculinity and religion study in Nigeria suggesting that supportive attitudes towards gender equality are consistent with certain church teachings on masculinity issues [50]. In this vein, a masculinity study carried out in the Assembly of God church in Zimbabwe found that men who were taught to be loving and non-violent in relationships with their female partners exhibited mutual support [51]. Similar studies have shown that some churches may be progressively contributing to changing gender norms, building and strengthening healthy family ties for men to partner constructively with their spouses and achieve gender equality [21, 52]. However, we are aware that not all churches are the same and not all pastors in the churches share similar perspectives regarding gender and sexuality.

\section{Study strengths and limitations}

Our study has a number of strengths, including the attempt to provide a general overview of church-going young men's beliefs and attitudes regarding the determinants of gender equality in marginalised areas in the DRC. The collaboration between the pastors and researchers contributed to reaching this vulnerable and under-researched population. Our study is not without limitations as the relative small sample size could not have identified some important relationships using logistic regression models. The views expressed by the respondents who mainly came from the Salvation Army might not have been representative of all-church going young men attending other churches in Kinshasa or in the rest of the country. Other possible limitations consisted in the fact that the study was based on self-reported attitudes and behaviours and the reliability of the responses could not be assessed and a potential bias might have taken place when parish pastors selected the participants.

Due to misunderstandings among participants about some statements, the survey tool was not self-administered for a few participants, potentially leading respondents to offer socially desirable responses. However, given the negative attitudes to equitable gender norms that church-going young men displayed, the interview techniques might not have significantly influenced their answers to please the investigator. Although the attitude and GEM questionnaires have been previously validated and extensively used in African contexts, we are aware that some statements might not have been fully understood in the same way by all the study participants, introducing a certain response bias.

The first author is the regional coordinator of EHAIA, a project of the World Council of Churches and is active in masculinity and gender equality work. Respondents may have provided responses to impress him (social desirability bias). Participants were encouraged to stick on statements of their choice and were ensured anonymity. The first author considered himself as having two perspectives: insider (working for a church) and outsider (as a researcher) in the research process [53]. He tried to manage these two perspectives by remaining a curious, open-minded and interested observer alongside the survey. The first author conducted this study in close collaboration with a study team of researchers that had different professional and national backgrounds. This collaboration process required several critical discussions and interpretations of the findings during the analysis, which resulted in agreements that enhanced data credibility.

\section{Conclusions}

To the best of our knowledge, this is the first study to measure views concerning gender norms using the GEM scale and some selected questions related to gender attitudes from IMAGES with church-going young men. Our study findings indicate that church-going young men are highly supportive of inequitable gender norms. However, being educated, living in Camp Luka and Masina, being single or separated, always attending the church and endorsing gender equitable attitudes were found to be key determinants associated with high scores on GEM. Our study calls attention to the need to involve church-going young men early in life in addressing inequitable attitudes, gender norms and deep-rooted ideologies of masculinities that it may be difficult to transform later during adulthood. Church-going young men with alternative views may present a key opportunity to reflect upon, challenge and change inequitable gender norms when they are equipped to do so before they may internalise societal messages that dictate (often negative) behaviours deemed appropriate for men. The inclusion of church-going young men as an indispensable part of gender equality and masculinity programmes in churches requires an approach that includes them not just as individuals but also as a collective. More intense promotional efforts are required as part of public education, early adolescent education and church policy and programme development related to gender equality. Further studies could be warranted to explore the determinants of gender equality from both female and male church-going youth's perspectives to ascertain any gender differences in this regard. 


\section{Appendix}

Table 4 Table regarding attitudes toward gender equality related to relations between men and women among church-going young men in Kinshasa

\begin{tabular}{|c|c|c|c|c|}
\hline Statements & Completely agree & Partly agree & Partly disagree & Completely disagree \\
\hline When women work, they are taking jobs away from men & $109(37.72)$ & $57(19.72)$ & $25(8.65)$ & $61(21.11)$ \\
\hline When women get rights, they are taking rights away from men & $91(31.49)$ & $71(24.57)$ & $42(14.53)$ & $55(19.03)$ \\
\hline Rights for women mean that men lose out & $51(17.65)$ & $41(14.19)$ & $44(15.22)$ & $101(34.95)$ \\
\hline $\begin{array}{l}\text { When a woman is raped, she usually did something careless to } \\
\text { put herself in that situation }\end{array}$ & $91(31.49)$ & $71(24.57)$ & $52(17.99)$ & $47(16.26)$ \\
\hline In some cases, women actually want it to happen & $67(23.18)$ & $80(27.68)$ & $38(13.15)$ & $73(25.26)$ \\
\hline If a woman did not fight back, you can't really say that it was rape & $117(40.48)$ & $77(26.47)$ & $31(10.73)$ & $46(15.92)$ \\
\hline $\begin{array}{l}\text { In any case one would have to question whether the victim is } \\
\text { promiscuous }\end{array}$ & $122(42.26)$ & $51(17.65)$ & 39 (13.49) & $57(19.72)$ \\
\hline $\begin{array}{l}\text { In any case one would have to question whether the victim has a } \\
\text { bad reputation }\end{array}$ & $88(30.45)$ & 78 (26.99) & 44 (15.22) & $58(20.07)$ \\
\hline
\end{tabular}

\section{Acknowledgements}

The authors wish to thank the Salvation Army and the Eglise du Christ au Congo leaderships for authorising this study to be carried out in their respective church premises. We would like also to thank church-going young men for giving their time and sharing their perspectives regarding gender equality.

\section{Funding}

This research was partially funded by the Umeå Centre for Global Health Research, funded by FAS, the Swedish Council for Working Life and Social Research, Grant number 2006-1512 and the Swedish Center Party Donation for Global Research Collaboration. The funding had no potential role in the design of the study and collection, analysis, and interpretation of data and in writing the manuscript.

\section{Availability of data and materials}

Data sharing not applicable to this article as no datasets were generated or analysed during the current study.

\section{Authors' contributions}

$\mathrm{HL}$ collected, analysed data and drafted the first version of this manuscript. MSS cross-checked the data and supervised the write up of the manuscript. $M C$ and KEE critically read the manuscript and equally contributed. All authors read and approved the final version of the manuscript.

\section{Ethics approval and consent to participate}

This study was approved by the institutional review board of the School of Public Health at the University of Kinshasa. Before doing the fieldwork, the first author requested written permission for the study from the Salvation Army and the Eglise du Christ au Congo leaderships.

\section{Consent for publication}

Written informed consent was obtained from all the study participants.

\section{Competing interests}

The authors declare that they have no competing interests.

\section{Publisher's Note}

Springer Nature remains neutral with regard to jurisdictional claims in published maps and institutional affiliations.

\section{Author details}

${ }^{1}$ World Council of Churches, Central Africa Regional Coordinator of the Ecumenical HIV and AIDS Initiative in Africa (EHAIA), C/o Salvation Army Headquarter, Avenue Colonel Ebeya no 23, B.P. 8636 Kinshasa Gombe, Democratic Republic of Congo. ${ }^{2}$ Department of Public Health and Clinical Medicine, Epidemiology and Global Health, Umeå University, Umeå, Sweden.
${ }^{3}$ Department of Nursing, Sexual and Reproductive Health, Umeå University, Umeå, Sweden.

Received: 31 July 2017 Accepted: 23 November 2017 Published online: 11 December 2017

\section{References}

1. Hawkes S, Buse K. Gender and global health: evidence, policy and inconvenient truth. Lancet. 2013;381:1783-9.

2. Connell RW. Change among the gatekeepers: men, masculinities and gender equality in the global arena. Signs. 2005;30(3):1801-25.

3. Pulverwitz J, Michaelis A, Verma R, Weiss E. "Looking back, moving forward: promoting gender equity to fight HIV, horizons studies 1999 to 2007", horizon synthesis background papers. Washington, DC: Population Council; 2010.

4. Barker G, Nascimento M, Segundo M, \& Pulerwitz J. How do we know if men have changed? Promoting and measuring attitude change with young men. In gender Equality and Men. Ruxton, S (ed.) Oxford, Oxfam. 2004.

5. Pulverwitz J, Barker G, \& Segundo M. Promoting healthy relationships and HIV/STI prevention for young men: positive findings from an intervention study in Brazil. Horizon Research Update. Population Council; Washington, DC. 2004

6. Verma RK, Pulerwitz J, Mahendra V, Khandekar S, Barker G, Fulpagare P, Singh SK. Challenging and changing gender attitudes among young men in Mumbai, India. Reproductive Health Matters. 2006;14(28):135-42.

7. Pulerwitz J, Martin S, Mehta M, Castillo T, Kidanu A, Verani F, Tewolde S. Promoting gender equity for HIV and violence prevention: results from the male norms initiative evaluation in Ethiopia. Washington, DC: PATH; 2010.

8. Barker G, Ricardo C, Nascimento M, Olukoya A, Santos C. Questioning gender norms with men to improve health outcomes: evidence of impact. Global Public Health. 2010;5(5):539-53.

9. Izugbara CO. Masculinity scripts and abstinence-related beliefs of rural Nigerian male youth. J Sex Resp. 2008;45(3):262-76.

10. Khangelani Z, Geofrey S, Thabile K, Thembile M, Thomas R. Age at sexual debut: a determinant of multiple partnerships among south African youth. Afr J Reprod Health. 2010:14(2):47-54.

11. Marston C, King E. Factors that shape young People's sexual behaviour: a systematic review. Lancet. 2006;368(9547):1581-6.

12. Mantell JE, Needham JA, Hoffman S, Cebekhulu Q, Adams-Skinner J, Exner TM, Mabude Z, Beksinska M, Stein ZA, Millford C. Gender norms in South Africa: implications for HIV and pregnancy prevention among African and Indian women students at a South Africa tertiary institution. Culture Health Sexuality. 2009;11(2):139-57.

13. Erulkar AS. The experience of sexual coercion among young people in Kenya. Int Fam Plan Perspect. 2004;30(4):182-9.

14. Pulverwitz J, Michaelis A, Verma R, Weiss E. Addressing gender dynamics and engaging men in HIV programmes: lessons learned from horizons research. Public Health Rep. 2010;125:282-92. 
15. Kato-Wallace J, Barker G, Sharafi L, Mora L, Laura G. Adolescent boys and young men: engaging them as supporters of gender equality and health and understanding their vulnerabilities. Washington, D.C: Promundo US, New York, UNFPA; 2016.

16. Stern E, Buikema R. The relational dynamics of hegemonic masculinity among south African men and women in the context of HIV. Cult Health Sex. 2015;15(9):1040-54.

17. Chitando E, Chirongoma S, editors. Redemptive masculinities: men, HIV and religion, EHAIA series. Geneva: World Council of Churches; 2012.

18. World Health Organisation. Building from common foundations. The World Health Organisation and Faith-based Organisations in Primary Health Care, Geneva. 2008.

19. Van Klinken AS. Theology, gender ideology and masculinity politics: a discussion on the transformation of masculinities as envisioned by African theologians and a local pentecostal church. J Theol South Afr. 2010;138:2-18.

20. Maskens M. The Pentecostal reworking of male identities in Brussels: producing moral masculinities. Etnografica. 2015;19(2):323-45.

21. Lusey $H$, Christianson M, San Sebastian M, Edin KE. Church representatives' perspectives on masculinities in the context of HIV. The case of the ecumenical HIV and AIDS initiative in Africa. Afr J AIDS Res. 2016;15(3):273-81.

22. Marshall M, Taylor N. Tackling HIV and AIDS with faith-based communities: learning from attitudes on gender relations and sexual rights within local evangelical churches in Burkina Faso, Zimbabwe, and South Africa. Gend Dev. 2006;14(3):363-74

23. Daniel K. The role of women in the church in Africa. Int J Sociol Anthropol. 2010;2(6):126-39.

24. Togarasei L. Christianity and hegemonic masculinities: transforming Botswana hegemonic masculinity using the Jesus of Luke. Scriptura. 2013; 112(1):1-12

25. Agadjanian C, Menjivar C. Talking about the "epidemic of the millennium": religion, informal communication, and HIV/AIDS in sub-Saharan Africa. Soc Probl. 2008:55(3):301-21.

26. Lusey H, San Sebstian M, Christianson M, Dahlgren L, Edin KE. Conflicting discourses of church youths on masculinity and sexuality in the context of HIV in Kinshasa, Democratic Republic of Congo. Sahara J. 2014;11(1):284-93.

27. Ricardo C, Nascimento M, Fonseca V, Segundo M. Programme $H$ and Programme M: Engaging young men and empowering young women to promote gender equality and health. Pan American Health Organisation and Promundo. Washington, D.C. 2010.

28. Slegh H, Barker G, and Levtov R. Gender relations and gender basedviolence and the effect of conflict on women and men in NorthKivu,Eastern DR Congo: Result from the International Men and Gender Equality Survey (IMAGES). Final report. Washington, DC, Cape Town, South Africa: Promundo-US \& Sonke Justice. 2014.

29. Central Intelligence Agency. The world factbook Africa: The Democratic Republic of Congo. Washington, DC. 2016.

30. International Center for Research on Women (ICRW) and Instituto Promundo. Men + Gender Equality: Policy Project: International Men and Gender Equality Survey (IMAGES). 2011.

31. Barker $G$, Contreras JM, Heilman B, Singh AK, Verma R, K \& Nascimento M. Evolving men: Initial Results from the International Men and Gender Equality Survey (IMAGES). Washington, DC: International Center for Research on Women (ICRW) and Instituto Promundo. 2011.

32. Pulerwitz J, Barker J. Measuring attitudes towards gender norms among young men in Brazil. Men Masculinities. 2008;10(8):322-38.

33. Levtov RG, Barker G, Contreras Urbina M, Heilman B, Verma R. Pathways to gender equitable men: findings from the international men and gender equality survey in eight countries. Men Masculinities. 2014:1-35.

34. Scott J, Averbach S, Modest AM, Hacker MR, Cornish S, Spencer D, Murphy M, Parmar P. A community assessment of gender inequitable norms and gender-based violence in South Sudan: a community-based participatory research approach. Confl Heal. 2013;7:4.

35. Jewkes R, Sikweyiya Y, Morell R, Dunkle K. Gender inequitable masculinity and sexual entitlement in rape perperation South Africa: findings of a cross-sectional study. PLoS One. 2011;6(12):e29590.

36. Epprecht M. Heterosexual Africa? The history of an idea from the age of exploration to the age of AIDS. Athens: Ohio University Press; 2008.

37. International for Research on Women (ICRW). The girl effect: what do boys have to do with it? Briefieng notes for an expert meeting and workshop. Washington, DC.
38. Nyanzi S, Nyanzi B, et al. Male promiscuity: the negotiation of masculinities by motorbike taxi-riders in Masaka, Uganda. Men Masculinities. 2009;12(1):73-89.

39. Walcott MM, Funkhouser E, Aung M, Kempf MC, Ehiri J, Zhang K, Bakhoya M, Hickam D, Jolly PE. Gender norms and sexual behaviours among men in western Jamaica. Sex Health. 2014;11:42-51.

40. Greene M, Omar R, Pawlak P. Masculinities, social change, and development World development report 2012. Gender equality and development. Background Paper. 2011.

41. Kazaura M, Ezekiel M, Chitama D, Mlang'a E. Gender equitable men's attitudes and beliefs to reduce HIV risk and gender based violence in Tanzania. Tanzan J Health Res. 2015:17(1):1-10.

42. Nanda G, Schuler SR, Lenzi R. The influence of gender attitudes on contraceptive use in Tanzania: new evidence using husbands' and wives' survey data. J Biosoc Sci. 2013;45:331-44.

43. Fulata FL. Sex, gender, power and HIV/AIDS in Malawi. Threats and challenges to women being church. J Constr Theol. 2005;10(1):85-102.

44. Vu L, Pulerwitz J, Burnett-Zieman B, Banura C, Okal J, Yam E. Inequitable gender norms from early adolescence to young adulthood in Uganda: tool validation and differences across age groups. J Adolesc Health. 2017;60(2):S15-21.

45. Kabiru CW, Izugbara CO, Beguy D. The health and well-being of young people in sub-Saharan Arica: an under-researched area? BMC Int Health Hum Rights. 2013:13:11.

46. Chitando E. A new man for a new era? Zimbabwean Pentecostalism, masculinities and the HIV prevention. Missionalia. 2007;35(5):112-27.

47. Simpson A. Boys to men in the shadows of AIDS: masculinity and HIV risk in Zambia. New York: Palgrave Macmilan; 2009.

48. Barker $\mathrm{G}$, et al. What men have to do with it: Public policies to promote gender equality. Washington, DC. International Center for Research on women. Available from http://www.icrw.org/docs/2010/What-Men-Have-toDo-With-It.pdf. 2010

49. Ratele K. Work through resistance in engaging boys and men towards gender equality and progressive masculinities. Cult Health Sex. 2015; 17(sup2):144-58.

50. Landmark research report. Masculinity and religion in Nigeria: findings from qualitative research. Christian Aid, Voices4Change and Islamic Relief. 2015.

51. Chitando E, Biri K. Faithful men of faithful god: masculinities in the Zimbabwe assembly of god Africa. Exchange. 2013;42(1):34-50.

52. Van Klinken AS. Men in the remaking: conversion narratives and born-again masculinity in Zambia. J Relig Afr. 2012;42(3):212-5.

53. Worris MW, Leung K, Ames D, Lickel B. Views from inside and outside: integrating Emic and Etic insights about culture and justice judgment. Acad Manage Rev. 1999;24(4):781-96.

\section{Submit your next manuscript to BioMed Central and we will help you at every step:}

- We accept pre-submission inquiries

- Our selector tool helps you to find the most relevant journal

- We provide round the clock customer support

- Convenient online submission

- Thorough peer review

- Inclusion in PubMed and all major indexing services

- Maximum visibility for your research

Submit your manuscript at www.biomedcentral.com/submit 